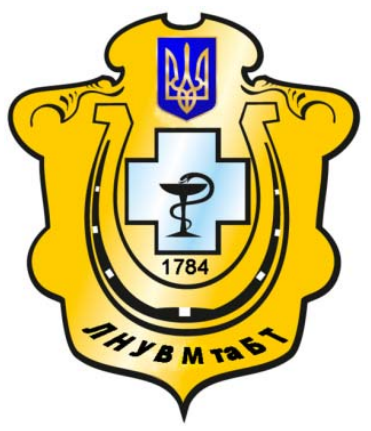

Науковий вісник Львівського національного університету ветеринарної медицини та біотехнологій імені С.3. Гжицького

Scientific Messenger of Lviv National University of Veterinary Medicine and Biotechnologies named after S.Z. Gzhytskyj

doi:10.15421/nvlvet6638

ISSN 2413-5550 print

ISSN $2518-1327$ online

$\underline{\text { http://nvlvet.com.ua/ }}$

УДК636.28.083.16

\title{
Резистентність і продуктивність кролів при використанні пробіотика «Евіталія» в умовах нормативного мікроклімату
}

\author{
М.В. Чорний, В.В. Кулак \\ vdmkulak@rambler.ru \\ Харківська державна зооветеринарна академія, \\ вул. Ювілейна, 1, смт Мала Данилівка, Дергачівський р-н, Харківська обл., 62341, Украӥна
}

Вивчено вплив пробіотика «Евіталія» на гематологічні, біохімічні та імунологічні показники кролів білий велетень в умовах нормативного мікроклімату. Дослідження виконані на молодняку кролів з народження до 120-денного віку, на двох групах тварин. Дослідним групам препарат задавали два рази на добу по 25 мл з народження до 30-денного віку, а потімпо 50 мл на голову (з 31 до 90-денного віку). Для оцінки впливу пробіотиків на організм кролика використовували гігієнічні методи дослідження (визначення температури і вологості, бактеріального обсіменіння повітря, освітленості); клінічні (температура тіла, частота пульсу та дихання); гематологічні (еритроцити, гемоглобін, лейкоцити); імунологічні (бактерицидна та лізочимна активність сироватки крові, фагоџичтарний індекс, фагоцитарна активність нейтрофілів (ФАН); зоотехнічні (жива маса і СДП), статистичні.

Дослідженнями встановлено, щзо використання кроликам пробіотичної закваски «Евіталія» у дозах 25 мл $і 50$ мл на голову двічі на добу протягом 5 днів з перервами 10 днів сприяють активачії окислювально-відновних процесів у кишечнику і в організмі в цілому, стимулячї гуморальних і клітинних факторів захисту, інтенсивному росту. В результаті досліджень виявлено наступне:

- збільшилася в крові кролів (вік 10-30-60 днів) кількість еритроцитів на 8,8-9,2\%, лейкоцитів - на 4,7 - 5,1\%, конщентрація гемоглобіну - на $5,3-7,1 \%$

- підвищилися гуморальні фактори захисту до значень: бактерищидна активність сироватки крові - до 36,46,0 \pm 0,3855,15 \pm 0,40\%, лізочимна активність сироватки крові - до 36,14 $\pm 0,79-40,18 \pm 0,83$;

- клітинні фактори захисту: фагоџитарний індекс - на 17 - 19,8\%, фагоцитарна активність нейтрофілів - на 10,1 $11,4 \%$;

- з'явився стимулюючий ефект за живою масою та середньодобовим приростом від використання пробіотика «Евіталія»

Ключові слова: кролі, жива маса, середньодобовий приріст, пробіотик «Евіталія», резистентність, бактерицидна та лізочимна активність сироватки крові, клітинні показники захисту, мікроклімат

\section{Резистентность и продуктивность кроликов при использовании пробиотика «Эвиталия» в условиях нормативного микроклимата}

\author{
Н.В. Черный, В.В. Кулак \\ vdmkulak@rambler.ru
}

Харьковская государственная зооветеринарная академия,

ул. Академическая, 1, пгт Малая Даниловка, Дергачёвский р-н, Харьковская обл., 62341, Украина

Изучено влияние пробиотика «Эвиталия» на гематологические, биохимические и иммунологические показатели кроликов бельй великан в условиях нормативного микроклимата. Исследования выполнены на молодняке кроликов с рождения до 120-дневного возраста, на двух группах животных. Опытным группам препарат задавали два раза в сутки по 25 мл с рождения до 30-дневного возраста, а затем - по 50 мл на голову (с 31- до 90-дневного возраста). Для оценки влияния

\section{Citation:}

Cherny, N.V., Kulak, V.V. (2016). The resistance and productivity of rabbits at use of probiotic «Evitaliya» in terms of regulatory climate. Scientific Messenger LNUVMBT named after S.Z. Gzhytskyj, 18, 2(66), 192-196. 
пробиотика на организм кролика использовали гигиенические методы исследования (определение температуры и влажности, бактериальной обсеменнености воздуха, освещенности); клинические (температура тела, частота пульса и дыхания); гематологические (эритрочиты, гемоглобин, лейкоциты); иммунологические (бактерицидная и лизоцимная активность сыворотки крови, фагоцитарный индекс, фагоцчитарная активность нейтрофилов (ФАН); зоотехнические (живая масса и ССП), статистические.

Исследованиями установлено, что использование кроликам пробиотической закваски «Эвиталия» в дозах по 25 мл и 50 мл на голову дважды в сутки в течение 5 дней с перерывами 10 дней, способствуют активации окислительновосстановительных прочессов в кишечнике и в организме в иелом, стимуляции гуморальных и клеточных факторов защиты, интенсивному росту. В результате исследований выявлено следуюшее:

- увеличилось в крови кроликов (возраст 10-30-60 дней) количество эритроцитов на 8,8 - 9,2\%, лейкоцитов - на 4,7 5,1\%, кониентрация гемоглобина - на 5,3-7,1\%

- повысились гуморальные факторы защчиты до значений: бактерицидная активность сыворотки крови-до 36,46,0 \pm

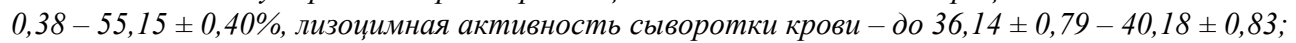

- клеточные факторы защчиты: фагоциттарный индекс - на 17 - 19,8\%, фагочитарная активность нейтрофилов - на $10,1-11,4 \%$;

- проявился стимулирующий эффект по живой массе и среднесуточным приростам от использования пробиотика «Эвиталия»

Ключевые слова: Кролики, живая масса, среднесуточный прирост, пробиотик «Эвиталия», резистентность, бактерицидная и лизоцимная активность сыворотки крови, клеточные показатели защчты, микроклимат.

\title{
The resistance and productivity of rabbits at use of probiotic «Evitaliya» in terms of regulatory climate
}

\author{
N.V. Cherny, V.V. Kulak \\ vdmkulak@rambler.ru \\ Kharkov State Zooveterinary Academy, \\ Akademichna Str., 1, Mala Danylivka, Kharkiv region, Dergachi district, 62341, Ukraine
}

The influence of probiotic «Evitaliya» hematological, biochemical and immunological parameters of the giant white rabbits in terms of regulatory climate. The studies were performed on young rabbits from birth until 120 days of age, two groups of animals. Experienced groups asked the drug twice a day for $25 \mathrm{ml}$ per head from birth to 30 days of age, and then $50 \mathrm{ml}$ on the head (from 31 - to 90-day age). To assess the effect of the probiotic on the body of the rabbit used hygienic methods of research (definition of temperature and humidity, bacterial obremenjenosti air, light); clinical (body temperature, pulse rate and respiration); hematological (erythrocytes, hemoglobin, leukocytes); immunological (bactericidal and lysozyme activity of blood serum, phagocytes index, phagocytes activity of neutrophils (FAN); livestock (live weight and SSP), statistical.

Studies found that the use of rabbits with probiotic ferment «Evitaliya» in doses of $25 \mathrm{ml}$ per head and $50 \mathrm{ml} /$ head twice a day for 5 days with breaks of 10 the bottom, contribute to the activation of redox processes in the intestine and the body as a whole, stimulation of humoral and cellular factors of protection, the intensive growth. The studies revealed the following:

- increased in the blood of rabbits (age 10-30-60 days) red blood cell count $8.8-9.2 \%$, leucocytes $-4,7-5,1 \%$, the concentration of hemoglobin - 5.3-7.1 per cent

- increased humoral factors of protection up to: bactericidal activity of blood serum - to $36.46,0 \pm 0.38-o f 55.15 \pm 0.40$ percent, lysozyme activity of blood serum to $36.14 \pm 0.79-40.18 \pm 0.83$;

- cellular factors of protection: the phagocytes index from 17 to 19,8\%, phagocytes activity of neutrophils - 10.1 - 11.4 per cent;

- manifested stimulating effect on live weight and average daily gain from the use of probiotic «Evitaliya».

Key words: Rabbits, live weight, average daily gain, probiotic «Evitaliya», resistance, bactericidal and lysozyme activity of blood serum, cell protection indicators, climate

\section{Вступ}

У збільшенні продуктів тваринництва важлива роль належить кролівництву, одній зі скоростиглих галузей дрібного тваринництва (Baksheev and Najmytenko, 1980; Miros' and Vakulenko, 1987; Vakulenko and Ochkovs'ka, 2007; Savchuk and Demchuk, 2009). Від кролиці і іï приплоду за рік можна отримати понад 100 кг м'яса.

Організм кроликів, як і інших с.-г. тварин, протягом життя підпадає під вплив абіо- і біотичних факторів, що обумовлюють депресію росту, зміну морфологічного складу крові, імунологічних показників (Garkavi et al., 1990; Demchuk and Savchuk, 2010; Medvedskij et al., 2013).

Обов'язковими умовами ефективного вирощування кроликів (Savchuk et al., 2012), стійких до факторів навколишнього середовища - це повноцінне збалансування годівлі, забезпечення оптимальних умов утримання та захист тварин від захворювань. В цьому аспекті заслуговують уваги використання БАР, що підвищують імунологічну реактивність, стимулюючи ріст, розвиток і резистентність (Sein and Aksenov, 2007; Vishnevskaja and Abramova, 2012; Jurashhak and Norejko, 2013).

Застосування пробіотичних препаратів молодняку тварин на ранніх стадіях вирощування нормалізують мікрофлору шлунково-кишкового тракту, стимулюють синтез імуноглобуліну IgA, підвищують його природну резистентність, активізують гомеостаз (Habibulov, 1989; Taraganov, 2000; Slobodjanik et al., 2009). Пробіотики готуються 3 мікроорганізмів, що представляють нормальну флору кишечнику, які доб- 
ре в ньому ростуть і синтезують інгібітори патогенних бактерій. Зараз в ряді країн світу [Швеція, Німеччина, Франція та ін.] відмовилися від застосування антибіотиків для стимуляції росту і стали більше уваги приділяти розробці та впровадженню в тваринництво імуномодуляторів і прибутків [бактерій, діталакт, лактімет і ін.], що дозволяють отримати екологічно чисту продукцію (Lesyk and Fedorchuk, 2005; Savchuk et al., 2012; Bagachyk, 2015).

Мета досліджень - вивчити вплив пробіотичної закваски «Евіталія» на морфологічні, імунологічні показники крові кроликів, а також їх ріст і розвиток в умовах нормативного мікроклімату.

\section{Матеріал і методи досліджень}

Дослідження проводилися на базі особистого подвір'я підприємця О.Д. Токарченко Краснолиманського району Донецької області (лютий - червень 2013 р.). Для проведення експерименту було сформовано дві групи кроленят 5-добового віку породи білий велетень - по 60 голів у кожній. Дослідній групі per os задавали двічі на добу пробіотик «Евіталія» крольчатам 3 народження до 30-денного віку по 25 мл на голову протягом 5 днів поспіль 3 перервами 10 днів, по 50 мл на голову - починаючи з 31- до 90-денного віку. Умови мікроклімату, освітленості, догляду були ідентичними і відповідали вимогам ВНТП - АПК 05.07- підприємства звірівництва і кролівництва. Контрольній групі кроликів per os задавали 0,9\% на- трію хлориду в тих же режимах і дозах, що і дослідній. Предметом досліджень була закваска «Евіталія», розроблена науково-виробничим об'єднанням «Пробиотик» (м. Москва). Евіталія - це ліофільно висушені спеціальні штами молочнокислих, ацидофільних паличок, лактококків, бактеріоцинів. Препарат містить вітаміни $\mathrm{B}_{1}, \mathrm{~B}_{2}, \mathrm{~B}_{6}, \mathrm{~B}_{12}, \mathrm{~A}, \mathrm{E}, \mathrm{C}$, фолієву кислоту, мікроелементи заліза, кальцію, магнію. Випускається у вигляді порошку, в одному флаконі «Евіталія» міститься $\left(2 \times 10^{9}+2 \times 10^{9}\right.$ КУО) понад 4 млрд. живих мікроорганізмів. Застосовується для відновлення кишкової мікрофлори, імунної системи, посилення гемопоезу, зниження стресових впливів. Вміст флакона розчиняли в 150 мл теплої кип'яченої води і задавали per os два рази в день: вранці та вдень по 25 і 50 мл на прийом.

Поставлена мета досягалася шляхом вирішення наступних завдань:

- вивченням зростання, середньодобових приростів і збереженості кроликів;

- виявленням впливу застосовуваного препарату «Евіталія» на клінічний статус, гематологічні показники, гуморальні та клітинні фактори захисту.

\section{Результати та їх обговорення}

Картина крові $є$ інформативним показниками, що характеризує зміни, які відбуваються в організмі кроликів (табл.1)

Табличя 1

Морфологічні показники крові кролів піддослідних груп

\begin{tabular}{|c|c|c|c|c|c|c|}
\hline \multirow{2}{*}{$\begin{array}{c}\text { Дослідження, } \\
\text { днів }\end{array}$} & \multicolumn{2}{|c|}{ Гемоглобін, г/л } & \multicolumn{2}{c|}{ Еритроцити, Т/л } & \multicolumn{2}{c|}{ Лейкоцити, Г/л } \\
\cline { 2 - 7 } & К & Д & К & Д & К & Д \\
\hline 5 & $89,35 \pm 1,20$ & $90,15 \pm 1,05$ & $6,03 \pm 0,11$ & $6,53 \pm 0,18$ & $6,50 \pm 0,80$ & $7,11 \pm 0,23$ \\
\hline 10 & $91,21 \pm 1,32$ & $96,11 \pm 0,93^{*}$ & $6,13 \pm 0,16$ & $6,67 \pm 0,20^{*}$ & $6,80 \pm 0,73$ & $7,12 \pm 0,18^{*}$ \\
\hline 30 & $91,62 \pm 1,50$ & $98,14 \pm 1,30^{*}$ & $6,17 \pm 0,18$ & $6,74 \pm 0,23^{*}$ & $6,04 \pm 0,52$ & $6,71 \pm 0,40$ \\
\hline 60 & $102,24 \pm 1,17$ & $108,53 \pm 1,27^{*}$ & $6,62 \pm 0,24$ & $7,18 \pm 0,42^{*}$ & $6,98 \pm 0,42$ & $7,34 \pm 0,25^{*}$ \\
\hline 190 & $111,4 \pm 2,03$ & $123,1 \pm 1,80$ & $7,01 \pm 0,08$ & $7,20 \pm 0,28$ & $7,20 \pm 0,31$ & $7,23 \pm 0,30$ \\
\hline
\end{tabular}

Примітка: достовірність різниці відносно до контролю: * $-\mathrm{P} \leq 0,05$.

Аналіз гематологічних показників свідчать, що кількість еритроцитів і лейкоцитів, концентрація гемоглобіну у тварин піддослідних груп не виходили за межі фізіологічних параметрів. У кроликів з дослідної групи достовірне збільшення концентрації гемоглобіну на $5,3 \%, 7,1 \%$ і 6,1\% встановлено на $10-30$ - і 60 день вирощування відповідно, за кількістю еритроцитів - перевищення виявлено в 10- i -30-денному віці
- відповідно на 8,8\% і 9,2\% (P $\leq 0,05)$, по лейкоцитам - на 4,7 і $5,1 \%(\mathrm{P} \leq 0,05)$ у кроликів 10 - і 60 - денного віку. Це свідчить про активізацію окислювальновідновних процесів і більш високі середньодобові прирости (СДП).

Гуморальні та клітинні показники найбільш об'єктивно характеризують рівень природної резистентності організму тварин (табл. 2).

Табличя 2

Показники природної резистентності молодняку кролів піддослідних груп

\begin{tabular}{|c|c|c|c|c|}
\hline Дослідження, днів & БАСК, \% & ЛАСК, $\%$ & ФІ, ед. & ФАН, \% \\
\hline \multirow{2}{*}{5} & $34,17 \pm 1,24$ & $21,38 \pm 0,07$ & $7,11 \pm 0,03$ & $32,18 \pm 1,20$ \\
\hline & $33,54 \pm 1,12$ & $22,14 \pm 0,005$ & $8,32 \pm 0,04^{*}$ & $35,46 \pm 2,01 *$ \\
\hline \multirow{2}{*}{15} & $40,03 \pm 1,20$ & $31,82 \pm 0,80$ & $7,45 \pm 0,03$ & $36,02 \pm 0,90$ \\
\hline & $47,55 \pm 1,17^{*}$ & $35,90 \pm 0,72$ & $8,76 \pm 0,02 *$ & $40,13 \pm 0,76^{*}$ \\
\hline \multirow{2}{*}{30} & $44,55 \pm 2,02$ & $32,91 \pm 1,11$ & $8,13 \pm 0,003$ & $35,14 \pm 0,52$ \\
\hline & $54,10 \pm 1,80^{*}$ & $37,76 \pm 0,81^{*}$ & $9,74 \pm 0,03 *$ & $37,71 \pm 0,39 *$ \\
\hline \multirow{2}{*}{60} & $43,00 \pm 0,33$ & $33,84 \pm 1,02$ & $7,33 \pm 0,29$ & $28,27 \pm 0,25$ \\
\hline & $55,15 \pm 0,86^{*}$ & $40,18 \pm 0,83^{*}$ & $8,41 \pm 33$ & $30,11 \pm 0,36$ \\
\hline \multirow{2}{*}{90} & $41,55 \pm 0,40$ & $32,71 \pm 0,9$ & $7,06 \pm 0,20$ & $27,63 \pm 0,19$ \\
\hline & $46,00 \pm 0,38$ & $30,14 \pm 0,79$ & $7,33 \pm 0,19$ & $29,14 \pm 0,239 *$ \\
\hline
\end{tabular}

Примітка: У чисельнику показники контрольної групи, в знаменнику - дослідної. 
3 гуморальних факторів захисту в забезпеченні високого рівня неспецифічної резистентності організму, відводиться бактерицидній активності сироватки крові (БАСК). Це здатність крові пригнічувати або затримувати ріст мікроорганізмів, що обумовлюється наявністю в ній лізоциму, компліменту, інтерферону, бактеріолізинів, здатних розчиняти клітини бактерії (А.І. Карелін, 1978, С.І. Плященко, 1991).

Найбільша БАСК щодо E.coli встановлена у кроленят 3 дослідної групи. При початковому значенні БАСК 34,17 - 33,54 $\pm 1,12 \%$ цей показник у тварин, яким задавали пробіотик «Евіталія», був вищим на 17,4 - 21,4\% (в 15 і 30 денному віці). До 60 і 90 денного віку він зріс на 10,8 - 12,8\% порівняно $з$ контролем і залишався на рівні 46,07 $\pm 0,38-55,15 \pm$ $0,40 \%$. Здатність сироватки крові затримувати ріст E.coli залишалася високою, особливо у кроликів 3 народження до 60-денного віку, в 3-місячному віці параметр БАСК не перевищував: в контролі 41,55 \pm 0,40\%, досліді $-46,07 \pm 0,38 \%$.

Лізоцим - найважливіший показник неспецифічної резистентності організму, який секретується гранулоцитами, моноцитами і макрофагами. Лізоцим здатний лізирувати полісахариди i викликати мобілізацію бета - лізинів, комплементу (С.С. Абрамов, 1989). У 5-денному віці ЛАСК коливалася в межах 21,38 \pm $0,07-22,14 \pm 0,05 \%$, а потім вона підвищувалася в дослідній групі в 15, 30, 60, 90-денному віці відповідно на $12,8 \%-14,7 \%, 18,7 \%$ і 10,4\% (P $\leq 0,05)$. 3 клітинних показників природної резистентності заслуговує на увагу фагоцитарний індекс (ФI) і фагоцитарна активність нейтрофілів (табл. 2).

У наших дослідженнях встановлено що, клітинні фактори захисту найбільш виражені були у кроленят 3 дослідної групи раннього віку (5, 15, 30-денного). Так, фагоцитарний індекс варіював від 8,32 $\pm 0,04$ до $8,76 \pm 0,02$ і $9,74 \pm 0,03$ і був на $17 \%,-17,5 \%$ і $19,8 \%$ вище в порівнянні з контролем. У 60 - і 90-денному віці цей показник не перевищував параметра 8,40 \pm 0,33 i 7,33 $\pm 0,19$. Аналогічна картина була i по фагоцитарної активності нейтрофілів.

3 віком цей показник клітинного захисту, порівняно з БАСК і ЛАСК, знижувався (P $\leq 0,05)$, хоча в цілому ФАН була вище в дослідній групі.

У період виконання досліду візуально контролювали стан апетиту, прийом води, температуру тіла ртутним термометром, число ударів пульсу і дихання - шляхом підрахунку (табл. 3.)

Таблиия 3

Клінічні показники кроликів піддослідних груп

\begin{tabular}{|c|c|c|c|c|c|c|}
\hline \multirow{2}{*}{ Показники } & \multicolumn{6}{|c|}{ Дні дослідження } \\
\hline & 5 & 10 & 30 & 60 & 120 & норма \\
\hline \multirow{2}{*}{$\begin{array}{c}\text { Температура тіла, } \\
{ }^{\circ} \mathrm{C}\end{array}$} & $39,2 \pm 0,11$ & $\underline{39,0 \pm 0,10}$ & $38,6 \pm 0,14$ & $38,8 \pm 0,41$ & $38,2 \pm 0,42$ & \multirow{2}{*}{$38,5-39,5$} \\
\hline & $39,3 \pm 0,23$ & $39,1 \pm 0,17$ & $38,6 \pm 0,32$ & $38,4 \pm 0,33$ & $38,6 \pm 0,57$ & \\
\hline \multirow[t]{2}{*}{ Частота пульсу, хв. } & $\underline{142,1 \pm 0,9}$ & $\underline{138,0 \pm 1,2}$ & $128,0 \pm 2,0$ & $\underline{136,0 \pm 1,24}$ & $134,0 \pm 2,0$ & \multirow{2}{*}{$120-140$} \\
\hline & $140,0 \pm 1,4$ & $141,0 \pm 1,4$ & $130,0 \pm 1,8$ & $134,0 \pm 1,36$ & $132,0 \pm 1,8$ & \\
\hline \multirow{2}{*}{$\begin{array}{c}\text { Частота дихання, } \\
\text { хв. }\end{array}$} & $\underline{73,4 \pm 0,4}$ & $70,0 \pm 0,50$ & $64,0 \pm 0,50$ & $\underline{56,0 \pm 0,30}$ & $64,0 \pm 0,11$ & \multirow{2}{*}{$50-60$} \\
\hline & $70,1 \pm 0,51$ & $64,0 \pm 0,40$ & $56,0 \pm 4,6$ & $52,0 \pm 0,21$ & $52,0 \pm 0,21$ & \\
\hline
\end{tabular}

Примітка: в чисельнику - показники з контрольної групи, знаменнику - дослідної.

У піддослідних кроликів не помічено відмови від корму і води, пригніченого стану. Параметри температури тіла, частоти пульсу і дихання були в межах фізіологічних норм, за винятком збільшення частоти дихання у кроленят 3 контрольної групи 5- і 10денного віку, що на наш погляд, обумовлене значно більшим споживанням кількості кисню через слабкий розвиток органів дихання (маса легень 10-25 г), що узгоджується 3 повідомленням Л.А. Білий, 1977 і Р.М. Сачук, 2012.

Найважливішими критеріями ефективності вирощування кроликів є зміна їхньої живої маси, середньодобові прирости та витрати кормів на одиницю продукції (табл. 4).

Табличя 4

Динаміка живої маси та середньодобових приростів кроликів

\begin{tabular}{|c|c|c|c|c|c|c|}
\hline \multirow{2}{*}{ Показники } & \multicolumn{6}{|c|}{ Вік, днів } \\
\hline & 1 & 15 & 30 & 60 & 90 & 120 \\
\hline \multicolumn{7}{|c|}{ Жива маса, г(ж.м) } \\
\hline & $61,3 \pm 0,1$ & $\underline{355,3 \pm 0,3}$ & $916,3 \pm 1,7$ & $\underline{2098,3 \pm 11,3}$ & $3322,3 \pm 31,2$ & $\underline{4258,3 \pm 18,7}$ \\
\hline & $60,8 \pm 0,1$ & $402,8 \pm 0,5$ & $1026,8 \pm 2,0^{*}$ & $2319,8 \pm 14,1^{*}$ & $3594,8 \pm 35,6^{*}$ & $4779,8 \pm 20,4$ \\
\hline \% до контролю & - & 113,3 & 112,2 & 110,5 & 108,2 & 112,2 \\
\hline \multicolumn{7}{|c|}{ Середньодобові прирости, г (СДП) } \\
\hline & & $\underline{19,6 \pm 0,6}$ & $\underline{37,4 \pm 0,1}$ & $\underline{39,4 \pm 0,11}$ & $\underline{40,8 \pm 0,19}$ & $\underline{31,2 \pm 0,15}$ \\
\hline & - & $22,8 \pm 0,1$ & $41,6 \pm 0,2^{*}$ & $43,1 \pm 0,12^{*}$ & $42,5 \pm 0,20$ & $39,5 \pm 0,12^{*}$ \\
\hline \% до контролю & - & 116,3 & 111,2 & 109,3 & 104,1 & 122,2 \\
\hline
\end{tabular}

Примітка: в чисельнику ж. м. і СДП - контрольної групи, знаменнику -дослідної; * $\leq 0,05$

Згідно 3 даними табл. 4 інтенсивність росту була вищою на $16,3 \%$ (1 - 15 день), на - 11,2\% (15 30 дн.), На 9,3\% (30 - 60 дн.) і 4,1\% (90-120 дн.). При цьому жива маса кроленят 3 дослідної групи в 90денному віці склала 3594,8 г, а в контрольній -
3322,3 г або на 8,2\% більше, конверсія корму 3,92 к.о./кг і 4,33 к.о./кг приросту, що на 10,4\% менше. Не менш важливим показником, що характеризує ефективність вирощування кроликів, $є$ збереження поголів'я. У нашому досліді вона склала - в контролі 
91,3\%, дослідній - 96,1\%. Причини загибелі обумовлені хворобами незаразного характеру: бронхіти, риніти, диспепсії.

Дослідження показали, що висока швидкість росту (за середньодобовими приростів), встановлена у молодняку кроленят 3 народження до 60-денного віку. Це дає підставу зробити висновок, що для стимуляції росту можна препарат застосовувати не протягом усього періоду вирощування, а з перервами.

Таким чином від використання пробіотичної добавки «Евіталія» отримано додатковий приріст живої маси (в розрахунку на одного кролика 4-місячного віку) 521,5 г або на 12,2\% більше в порівнянні $з$ контрольною групою.

\section{Висновки}

Застосування кроликам пробіотика «Евіталія» позитивно позначилося на гематологічних, біохімічних і імунологічних показниках: крові, інтенсивності росту і розвитку, що проявилися в наступному:

- збільшенням в крові кроликів (вік 10, 30 і 60 днів) кількості еритроцитів на 8,8 і 9,2\%, лейкоцитів на 4,7 - 5,1\%, концентрації гемоглобіну - на 5,3 $7,1 \%$;

- активізацією до значень: БАСК - 46,07 $\pm 0,38-$ $55,15 \pm 0,40 \%$, ЛАСК $-36,14 \pm 0,79-40,18 \pm 0,83 \%$, підвищенням ФІ - на 10,1 - 11,4\%;

- стимуляцією росту і СДП, особливо у кроленят 3 народження до 60-денного віку, що дозволяє скоротити час їх утримання під кролематки.

Препарат рекомендуємо застосовувати кроликам до 30-денного віку в дозі 25 мл/голову двічі на добу, старшого віку - по 50 мл/голову.

Перспективи подальших досліджень. Подальші дослідження будуть спрямовані на використання інших БАР при вирощуванні кроликів порід шиншила i сірий велетень.

\section{Бібліографічні посилання}

Baksheev, P.D., Najmytenko, E.P. (1980). Potochnoe proizvodstvo mjasa krolikov. M. (in Russian).

Bagachyk, O.G. (2015). Analyz vidminnostej u zakonodavstvi Ukrai'ny na ES po dobrobutu produktyvnyh tvaryn. Dobrobut produktyvnyh tvaryn u konteksti garmonizacii' zakonodavstva Ukrai'ny ta Evropejskogo sojuzu: Mat. mizhn. nauk.-prakt. konferencii' 27 lystopadu 2015 r. - Bila Cerkva, 4-27 (in Ukrainian).

Vakulenko, I., Ochkovs'ka, T. (2007). Vidrodzhennja galuzi krolivnyctva. Tvarynnyctvo Ukrai'ny. 10, 2-4 (in Ukrainian).
Vishnevskaja, T.Ja., Abramova, L.L. (2012). Gematologicheskie pokazateli krolikov v uslovijah stressa i pri ego immunokorrekcii. Akt. prob. intensivnogo razvitija zhivotnovodstva: sb. nauch. tr. Gorki. 15(2), 203-206 (in Russian).

Garkavi, L.K., Kvakina, E.B., Ukolova, M.A. (1990). Adaptacionnye reakcii i rezistentnost' organizma. Rostov N/D (in Russian).

Medvedskij, V.A., Sadomov, N.A., Shhebetja, I.V. i dr. (2013). Gigienicheskie normativy po soderzhaniju krolikov i pushnyh zverej: rekomendacii. Vitebsk: VGAVM (in Russian).

Demchuk, M.V., Savchuk, R.M. (2010). Pidvyshhennja jakosti produkcii' krolivnyctva na okremyh tehnologichnyh etapah. Nauk.visnyk LNUVMBT im. S.Z. Gzhyc'kogo. L'viv. 12. 3(45), 173-179 (in Ukrainian).

Lesyk, Ja.V., Fedorchuk, R.S. (2005). Rezystentnist' organizmu ta intensivnost' rostu kroliv zalezhno vid periodu vidluchennja. Visnyk Dnipropetrovs'kogo agrarnogo un-tu. - Dnipropetrovs'k. 2, 111-214 (in Ukrainian).

Miros', V.V., Vakulenko, I.S. (1987). Metodicheskie rekomendacii po tehnologi intensivnogo proizvodstva mjasa krolikov na promyshlennyh krolefermah (in Russian).

Savchuk, R.M., Demchuk, M.V. (2009). Intensyvni tehnologii'- perspektyvy rozvytku krolivnyctva. Sil'skyj gospodar, 11-12, 29-30 (in Ukrainian).

Savchuk, R.M., Demchuk, M.V., Kamuns'ka, L.P. (2012). Osnova vidrodzhennja krolivnyctva - zagal'na veterynarna profilaktyka. Sil'skyj gospodar. 9-10, 11-16 (in Ukrainian).

Sein, B.S., Aksenov, A.A. (2007). Integral'nye pokazateli u krolikov pri immobilizacionnom stresse. Problemy s. - h. proizvodstva na sovremennom jetape i puti ih reshenija: Mat. XI mezhd. nauchno-proiz. konf. Belgorod, 217 (in Russian).

Slobodjanik, V.I., Zhukov, S.P., Slobodjanik, M.V. (2009). Immunomoduljatory rinkolejkin i fosprinil pri vyrashhivanii krolikov. Krolikovodstvo i zverovodstvo. 1, 27-28 (in Russian).

Taraganov, M.A. (2000). Mehanicheskie dejstvija probiotikov na mikrofloru pishhevaritel'nogo trakta na organizm zhivotnogo. Veterinarija, 5, 32-33 (in Russian).

Habibulov, M.A. (1989). Gigiena v promyshlennom krolikovodstve (in Russian).

Jurashhak, S.V., Norejko, A.Ju. (2013). Jeffektivnost' proizvodstva mjasa krolikov pri soderzhanii v zakrytom krol'chatnike. Akt problemy intensivnogo razvitija zhivotnovodstva. Gorki, 16(1), 322-329 (in Russian).

Стаття надійшла до редакичї 1.09.2016 